$\mathbf{R}_{\text {ESEARCH }} \mathbf{P}_{\text {APER }} \longrightarrow$ FOOD SCIENCE e ISSN-2230-9403 Visit us :

www.researchjournal.co.in

Volume 9 | Issue 1 | April, 2018 | 198-200

DOI : 10.15740/HAS/FSRJ/9.1/198-200

\title{
Quality evaluation of selected Kulfi samples sold in the market of Bikaner city (Rajasthan)
}

\author{
Roopam Gupta and Madhu Goyal
}

Dairy products are universally known for their nutritional and therapeutic values. Kulfi is the popular Indian frozen concentrated milk product, which is an ice cream like product, has been quoted in literature in different ways like Kulfi, Kulffi, Kulafi, Kulfy, Kulphy. Kulfi which is one of the most popular and nutritious dairy product can sometimes become a potential source of health hazard, by causing food poisoning outbreaks or by acting as a carrier of pathogens or by adulteration. The present study was attempted to evaluate the quality of Kulfi. For this, samples were collected in triplicates in previously sterilized containers, from five prominent shops of Bikaner city. The average moisture, crude protein, fat, total ash, carbohydrate, energy, calcium and phosphorus content was ranged from 42.36-57.20 g \%, 6.56-9.28 $\mathrm{g} \%, 10.13-18.56 \mathrm{~g} \%, 3.35-4.35 \mathrm{~g} \%, 15.01-35.16 \mathrm{~g} \%, 233-273 \mathrm{Kcal}, 683-718 \mathrm{mg} \%$, and 736-901 mg \%, respectively. Forty per cent and 20 per cent samples were noted to be of satisfactory quality with respect to SPC and faecal streptococcal count, respectively. Presence or absence of adulterants like starch and metanil yellow were also detected, but all the samples were found to be devoid of starch but in 20 per cent samples the inedible color that is metanil yellow was present . With respect to the possibility of adulteration and microbial contamination, quality of Kulfi remains in question.

Key Words : Quality, Bacteriological examination, Adulteration, Health hazard, Microbial count

How to cite this article : Gupta, Roopam and Goyal, Madhu (2018). Quality evaluation of selected Kulfi samples sold in the market of Bikaner city (Rajasthan). Food Sci. Res. J., 9(1): 198-200, DOI : 10.15740/HAS/FSRJ/9.1/198-200. 